\title{
A learning skills course for the Ist year medical students: an experience at a Saudi medical school
}

This article was published in the following Dove Press journal:

Advances in Medical Education and Practice

23 March 2015

Number of times this article has been viewed

Imran A Siddiqui'

Khalid A Bin Abdulrahman²

Mohammed A Alsultan ${ }^{3}$

'Department of Medical Education and Postgraduate Studies, Saudi

Commission for Health Specialties, Riyadh, Saudi Arabia; ${ }^{2}$ College of Medicine, Al-Imam Muhammad Ibn Saud Islamic University (IMSIU), Riyadh, Saudi Arabia; ${ }^{3}$ College of Medicine, King Saud bin Abdulaziz University for Health Sciences, Riyadh, Saudi Arabia

Correspondence: Imran A Siddiqui Department of Medical Education and Postgraduate Studies, Saudi Commission for Health Specialties, PO Box 94656 Riyadh II6I4, Saudi Arabia

Tel+966 II $29057 \mid 4$

Email siddiquiimra@gmail.com
Background: Every year nearly 1,500 students enter into medical program after passing high school and national aptitude exams. However, many students experience frustration, failure, and psychological morbidities like stress, depression, and anxiety because they are not aware of their learning styles or do not have effective learning skills and strategies. The College of Medicine of Al-Imam Muhammad ibn Saud Islamic University has adopted the outcome based, community oriented, Spiral Curriculum. Although the curriculum is innovative, on the other hand, it is very demanding.

Objective: The purpose of this paper is to share educational structure and evaluation results of the course on effective learning and study skills for the 1st year medical students.

Methods: To prepare our students in order to cope with this demanding but promising curriculum, we conducted an effective and comprehensive learning skills course for 16 weeks in the first semester of year 1 in the medical program. Performance of each student was assessed and the course evaluation was done by students at the end of the course.

Results: The attendance of the students throughout the course was over $90 \%$. The average performance of students in the summative assessment was $78 \%$ and the course was generally liked by the students.

Discussion: Students overall had a positive attitude toward the learning skills course. Majority of the students showed interest in attending the sessions regularly and realized the significance of this course to improve their learning skills.

Keywords: medical students, learning skills, Saudi students

\section{Introduction}

A lot has been written on the transition of students from high school to 1 st year medical education. ${ }^{1-3}$ It can be difficult for students because of the dramatic increase in the volume of content. Furthermore, today's medical students represent a broad spectrum in terms of age, experience, culture, ethnicity, and level of preparedness as well as learning preferences and styles. ${ }^{4,5}$ It is not coming as a surprise to serious students that the process of learning itself must be learned. However, after years of formal schooling, many students enter higher education and graduate programs without having mastered these fundamental skills. When they start a professional medical program and are propelled into a more active learner mode, understanding of these fundamentals become vital. ${ }^{6}$ Many medical students quickly realize that they need to assimilate considerable new information during their studies especially with the need for evidence-based practice and grasping exponential increase in the relevant new information, and they need to develop skills for lifelong learning and keeping their knowledge updated. Those students who 
fail to realize that, face difficulty in coping with the demand of the program and come under huge academic pressure, resulting in their poor academic performance. ${ }^{?}$

A huge number of published studies from different parts of the world show that there is a high prevalence of psychological morbidity like anxiety, stress, and depression among the undergraduate medical students. ${ }^{89}$ In 2011, very high prevalence of stress among females and males was reported, $75.7 \%$ and $57 \%$ respectively, in one of the medical school of Saudi Arabia. ${ }^{10}$ Sometimes, coping strategies adopted by the students worsen the situation. There are some studies which examined the coping strategies of undergraduate medical students with stress. Results of these studies show that some students adopted coping strategies like sports, music, and hanging out with friends. On the other hand some students started to use tobacco, drugs, and alcohol in order to cope with the stress. ${ }^{11,12}$ The studies have classified the sources of stress into three main areas: academic pressures, social issues, and financial problems but academic pressure has been pointed out as a key source of stress. ${ }^{13}$ In addition to educating in a professional medical course it is also important to take into account the quality of life of the students during the years of medical training which is related to long study hours, lack of peer support, competitive environment, rigid authoritative and non-encouraging faculty, an imbalance between professional and personal lives, lack of recreational activities, staying away from home, financial problems, an uncertain future, emergency situations, speedy decisions, mismatch between capability and expectation, etc. ${ }^{14}$

Whatever the reasons, it is a well-known fact that the transition from high school to medical school is a difficult period which often results in frustration and poor academic performance in their medical program. Mostly, it is not because they lack ability but because they are not aware of their learning styles or do not have effective learning skills and strategies. Though some medical schools have a system of student counseling and other supporting programs there is still a scarcity of properly structured courses on learning skills. ${ }^{15}$

The objective of the study is to share our experience of conducting a learning skills course for 1 st year medical students describing the conceptual framework, content, instructional strategy and assessment of the course, and the feedback from the students. This course was conducted with the aim to improve learning skills of students so they can overcome the challenges they may face during their medical program.

\section{Methods}

The learning skills course was conducted at the College of Medicine at Al-Imam Muhammad Ibn Saud Islamic
University, Riyadh, Kingdom of Saudi Arabia. The undergraduate medical curriculum at this university is outcome based, integrated, problem based, and community oriented. The curriculum features a spiral approach that reinforces key topics by revisiting them in different contexts with increasing sophistication throughout the year. Some aspects of the past are also explored in increasing detail at a number of levels. Since this school has adopted the spiral approach, the knowledge and skills of the students are growing with the growth of the curriculum. The objective of the medical program at this school is to shift educational emphasis from the learning of the facts to teaching students the skills that they will need to be an effective lifelong learner.

The undergraduate curriculum in 1st year (consists of two semesters each), is included in the preclinical phase and consists of seven longitudinal courses running throughout the semester that spans 16 weeks. Along with these longitudinal courses there are four blocks for a limited number of weeks using problem-based learning (PBL) as a major instructional method. The longitudinal courses are: Human Body I, Human Body II, Communication Skills, Islamic Studies, History of Medicine, Quran, and Learning Skills. The problem-based blocks in 1st year are: Growth and Development, Principle of Diseases I, Principle of Diseases II, and Molecular Basis of Diseases. The learning skills course is offered in the first semester of 1 st year medical program.

The course was designed to achieve some of the competencies listed in the Saudi Meds Framework such as teamwork and inter-professional collaboration, clinical reasoning and decision making, communication skills, professionalism, leadership, information technology, and research. A planning committee was formulated to design the course. The aim of the course was defined first. In order to achieve the aim of the course, general learning outcomes were identified. These general outcomes were further elaborated by identifying the specific learning outcomes. To achieve the learning outcomes instructional activities were designed. The course was composed of 14 interactive sessions, once a week in the semester, each for 2 hours. Out of the 14 sessions, eight were interactive sessions, four were seminars, and two were large group exercises (Table 1). Six out of the eight interactive tutorial sessions were conducted by in-house faculty members and for the remaining two local experts were invited. Seminars were presented by the students in groups which were formed at the start of the semester. An expert was appointed for each seminar session to supervise the seminar groups in order to facilitate the students in identifying the learning outcomes and required resource to prepare the seminar topic. For two 
Table I List of activities included in the course with methods for conducting

\begin{tabular}{|c|c|c|}
\hline $\begin{array}{l}\text { Activity } \\
\text { number }\end{array}$ & Activity title & $\begin{array}{l}\text { Method of } \\
\text { activity }\end{array}$ \\
\hline 1 & New Trends in Medical Education & Interactive session \\
\hline 2 & Learning Styles & Exercise \\
\hline 3 & Saudi Meds Framework & Seminar \\
\hline 4 & $\begin{array}{l}\text { Orientation to curriculum } \\
\text { contents and regulation }\end{array}$ & Interactive session \\
\hline 5 & $\begin{array}{l}\text { Instructional Methods in Medical } \\
\text { Education }\end{array}$ & Seminar \\
\hline 6 & Rationale and Principles of PBL & Interactive session \\
\hline 7 & The Process of PBL & Exercise \\
\hline 8 & Stress Management & Interactive session \\
\hline 9 & Learning Resources & Seminar \\
\hline 10 & Mind Mapping & Interactive session \\
\hline 11 & Critical Thinking & Interactive session \\
\hline 12 & The professional students & Interactive session \\
\hline 13 & Methods of Assessment & Seminar \\
\hline 14 & Evaluation and Feedback & Interactive session \\
\hline
\end{tabular}

Abbreviation: PBL, problem-based learning.

exercises, facilitators were appointed who were experts in those areas. We used short introductory presentation in order to make the students aware of the dimensions and theme of the course.

Total number of students enrolled in the course was 128 . The criterion for registration in this course was the successful completion of the preparatory year program. The study guide of the course was distributed electronically to the registered students, faculty members, and invited instructors involved in the course, 1 week prior to the start of the course. The study guide contained all required information including the course title, code, the name and contact information of course planners, aims, general and specific objectives of the course, title of the sessions with instructional methods, schedule, required references, etc.

For the purpose of the students' assessment, $60 \%$ was given to continuous assessment which was further broken down into $50 \%$ for mid-course written exam and $10 \%$ for seminar assessment, while $40 \%$ was given to end of the course written exam. The planning committee of the course formulated a table of content specification (assessment blueprint) to ensure the validity and balance in assessment items. To assess seminar sessions, two evaluators were appointed for each session who evaluated the students independently for the quality of the content and presentation using an evaluation sheet. Then the scores were submitted to the course planner to finalize the marks scored by the student after reviewing the inter-rater reliability and rating the obtained scores. The rating scale used to grade seminar sessions was as follows:
5. Excellent: the quality has been demonstrated to an exceptional level; a professional performance; a performance well above the expected level for a student.

4. Very good: the quality has been demonstrated to a high standard; the student has reached a level which clearly exceeds "competency".

3. Good: the quality is clearly demonstrated without being exceptional in any way; students can be thought of as being competent in respect of this quality.

2. Satisfactory: the quality has been demonstrated to a minimally acceptable level; there may be flaws but these are not serious enough to fail the student on this quality.

1. Poor: the quality is absent or performed to a very low level, or the performance is seriously flawed.

Rating scores were then entered into the final score sheet, made on a 100-point scale for pass, fail, and grading decisions. Maximum points from seminar scores were carrying $10 \%$ on 100 -point scale.

The written exam consists of Type-A multiple choice questions and short essay questions selected according to the assessment blue print, generated before the start of the course. The items were reviewed vigorously by two experts for quality and validity.

The informal feedback from the students regarding the course was obtained in the middle of the course which is 8 weeks after the start of the course, while formal feedback was also obtained at the end of the course, using a questionnaire. The purpose of using a questionnaire was the evaluation of the course by the students and their opinion about each individual session which would be helpful in the planning of the same course for the next year. The questionnaire consisted of 29 Likert type rating items, regarding the educational context, content, management in conducting the course, and three open-ended questions to receive further comments. The open-ended questions regarding the general "likes", "dislikes", and suggestions for the improvement of the quality of the course were: "what did you like most about this course?"; "what did you dislike most about this course?"; and "what suggestions do you have to improve this course?" Responses to the items on the feedback questionnaire and open-ended questions were analyzed and noted.

\section{Results}

The attendance of the students during the whole course was more than $90 \%$. All the sessions were conducted during the scheduled time as mentioned in the course guide book. The average score in the mid-course exam was $72.5 \%$. 
The average collective score including the continuous assessment and end of the course exam was $78 \%$.

The analysis of the course survey showed that the majority of the students stated their enjoyment of the course in general and felt that the course would be helpful in making them good doctors. Ninety-two (71.9\%) out of 128 students agreed that exercises were complementary to the course and were very useful. None of the survey items has received the most popular response for the disagreement and $16.4 \%$ was the maximum percentage of the students who stated their disagreement in one of the items of the questionnaire (Table 2).

The other part of the questionnaire contained the title of the sessions in which students were asked to rate each session. The analysis of this questionnaire revealed that most of the sessions were rated as "excellent" or "good" while none of the sessions was rated as "useless" by more than $5 \%$ of the students. Both the exercises (process of PBL and learning styles) included in the course, received the highest rating among all sessions (Table 3 ). The analysis of the open-ended questions showed that 106 students mentioned their enjoyment of various aspects of the course, eg, sessions, faculty, interest in the course; 22 students mentioned their dislike of some of the aspects, eg, a specific facilitator, duration of the sessions; and 60 students stated their suggestions to improve the course in future.

\section{Discussion}

Medical education is a lifelong process. There is too much information and not enough time. Even along with the existing information, there is a continuous explosion of new knowledge and medical teachers are struggling to provide the maximum amount of it to their students. Often it is frustrating for teachers and students because it can actually lead to less learning if the students are not aware of the art and skills of learning. The point is not to present information but to get learners to remember and use it. So, the focus of medical education should be the learner and facilitating learning instead of inhibiting it. ${ }^{16}$ However, the current system of medical education in many of the medical schools is often

Table 2 Course evaluation survey

\begin{tabular}{|c|c|c|c|c|c|}
\hline $\begin{array}{l}\text { Questions } \\
\text { n (\%) }\end{array}$ & $\begin{array}{l}\text { Strongly } \\
\text { agree }\end{array}$ & Agree & $\begin{array}{l}\text { True some } \\
\text { of the time }\end{array}$ & Disagree & $\begin{array}{l}\text { Strongly } \\
\text { disagree }\end{array}$ \\
\hline & 5 & 4 & 3 & 2 & $\mathbf{I}$ \\
\hline $\begin{array}{l}\text { I. The course objectives are clear to you from } \\
\text { the start of the course }\end{array}$ & $30(23.44 \%)$ & $33(25.78 \%)$ & 40 (31.25\%) & $17(13.28 \%)$ & $8(6.25 \%)$ \\
\hline $\begin{array}{l}\text { 2. The study guide book was provided to you at } \\
\text { the beginning of the course }\end{array}$ & 55 (42.97\%) & 31 (24.22\%) & $18(14.06 \%)$ & $18(14.06 \%)$ & $8(6.25 \%)$ \\
\hline 3. The study guide book was helpful in your study & $27(21.09 \%)$ & $17(13.28 \%)$ & $52(40.63 \%)$ & $20(15.63 \%)$ & $12(9.38 \%)$ \\
\hline $\begin{array}{l}\text { 4. The list of learning resources has been } \\
\text { provided to you }\end{array}$ & $27(21.09 \%)$ & $30(23.44 \%)$ & $44(34.38 \%)$ & $20(15.63 \%)$ & $10(7.81 \%)$ \\
\hline $\begin{array}{l}\text { 5. The learning resources were appropriate } \\
\text { and useful }\end{array}$ & $20(15.63 \%)$ & $30(23.44 \%)$ & $44(34.38 \%)$ & 21 (16.41\%) & $14(10.94 \%)$ \\
\hline $\begin{array}{l}\text { 6. The course coordinator was available when } \\
\text { I faced a problem during the course }\end{array}$ & $30(23.44 \%)$ & $36(28.13 \%)$ & 37 (28.9 I\%) & $19(14.84 \%)$ & $5(3.91 \%)$ \\
\hline $\begin{array}{l}\text { 7. The course was conducted according to the } \\
\text { course outline }\end{array}$ & $23(17.97 \%)$ & $4 \mathrm{I}(32.03 \%)$ & $44(34.38 \%)$ & II (8.59\%) & $6(4.69 \%)$ \\
\hline $\begin{array}{l}\text { 8. Exercises (mock PBL and learning styles) were } \\
\text { complementary to the course and very useful }\end{array}$ & $50(39.06 \%)$ & $42(32.81 \%)$ & $21(16.41 \%)$ & $9(7.03 \%)$ & $5(3.91 \%)$ \\
\hline $\begin{array}{l}\text { 9. The teachers are punctual in terms of the } \\
\text { educational activity dates and times }\end{array}$ & $26(20.31 \%)$ & $34(26.56 \%)$ & $50(39.06 \%)$ & II (8.59\%) & $6(4.69 \%)$ \\
\hline 10. Teaching staff of this course is excellent & 40 (31.25\%) & $39(30.47 \%)$ & $36(28.13 \%)$ & II (8.59\%) & $3(2.34 \%)$ \\
\hline $\begin{array}{l}\text { II. Faculty staff respect the students and we have } \\
\text { a good relationship with them }\end{array}$ & $64(50.00 \%)$ & $28(21.88 \%)$ & 31 (24.22\%) & $5(3.91 \%)$ & $0(0.00 \%)$ \\
\hline $\begin{array}{l}\text { 12. Amount of time in which exam needs to be } \\
\text { completed is appropriate for the number of } \\
\text { questions }\end{array}$ & 55 (42.97\%) & $32(25.00 \%)$ & $19(14.84 \%)$ & $13(10.16 \%)$ & $8(6.25 \%)$ \\
\hline $\begin{array}{l}\text { 13. Exam questions are reasonable and from the } \\
\text { curriculum }\end{array}$ & $29(22.66 \%)$ & $38(29.69 \%)$ & 39 (30.47\%) & II (8.59\%) & $8(6.25 \%)$ \\
\hline $\begin{array}{l}\text { 14. I feel that this course will make me a better } \\
\text { doctor }\end{array}$ & $26(20.31 \%)$ & $45(35.16 \%)$ & $45(35.16 \%)$ & $10(7.81 \%)$ & $3(2.34 \%)$ \\
\hline 15. I am happy with this course in general & $30(23.44 \%)$ & $4 \mid(32.03 \%)$ & $38(29.69 \%)$ & II (8.59\%) & $7(5.47 \%)$ \\
\hline
\end{tabular}

Note: Bold figures represent the highest number of responses in each question. Abbreviation: PBL, problem-based learning. 
Table 3 Rating of the sessions conducted during the course according to the title of session

\begin{tabular}{|c|c|c|c|c|c|c|}
\hline \multirow[t]{3}{*}{ Title of the session } & \multicolumn{6}{|c|}{ Rating of the sessions conducted during the course } \\
\hline & Excellent & Good & Fair & Bad & Useless & Average \\
\hline & 5 & 4 & 3 & 2 & $\mathbf{I}$ & Out of 5 \\
\hline I. New Trends in Medical Education & $43(33.59 \%)$ & $48(37.50 \%)$ & $19(14.84 \%)$ & $6(4.69 \%)$ & $5(3.91 \%)$ & 3.76 \\
\hline 2. The Future Saudi Doctors & 55 (42.97\%) & $40(31.25 \%)$ & $21(16.41 \%)$ & $8(6.25 \%)$ & $3(2.34 \%)$ & 4.04 \\
\hline $\begin{array}{l}\text { 3. Orientation to curriculum contents } \\
\text { and regulation }\end{array}$ & $36(28.13 \%)$ & $53(41.41 \%)$ & $27(21.09 \%)$ & $7(5.47 \%)$ & $4(3.13 \%)$ & 3.84 \\
\hline 4. Instructional Methods in Medical Education & $23(17.97 \%)$ & 49 (38.28\%) & $43(33.59 \%)$ & $8(6.25 \%)$ & 5 (3.9l\%) & 3.60 \\
\hline 5. Rationale and Principles of PBL & $52(40.63 \%)$ & $45(35.16 \%)$ & $23(17.97 \%)$ & $4(3.13 \%)$ & $3(2.34 \%)$ & 4.06 \\
\hline 6. The Process of PBL & $64(50.00 \%)$ & $33(25.78 \%)$ & $25(19.53 \%)$ & $4(3.13 \%)$ & $3(2.34 \%)$ & 4.20 \\
\hline 7. Stress Management & $42(32.81 \%)$ & $38(29.69 \%)$ & 31 (24.22\%) & $12(9.38 \%)$ & $5(3.91 \%)$ & 3.78 \\
\hline 8. Methods of Assessment & $34(26.56 \%)$ & $47(36.72 \%)$ & $30(23.44 \%)$ & II (8.59\%) & $6(4.69 \%)$ & 3.72 \\
\hline 9. Learning Styles & $52(40.63 \%)$ & $42(32.81 \%)$ & $24(18.75 \%)$ & $10(7.81 \%)$ & $2(1.56 \%)$ & 4.08 \\
\hline 10. Mind Mapping & $48(37.50 \%)$ & $30(23.44 \%)$ & $33(25.78 \%)$ & $13(10.16 \%)$ & $3(2.34 \%)$ & 3.81 \\
\hline II. Critical Thinking & 49 (38.28\%) & $32(25.00 \%)$ & $26(20.31 \%)$ & $13(10.16 \%)$ & 5 (3.9l\%) & 3.77 \\
\hline 12. Learning Resources & $30(23.44 \%)$ & $43(33.59 \%)$ & $42(32.81 \%)$ & 7 (5.47\%) & $3(2.34 \%)$ & 3.63 \\
\hline 13. The professional students & 48 (37.50\%) & $4 \mathrm{I}(32.03 \%)$ & $26(20.31 \%)$ & $6(4.69 \%)$ & 5 (3.91\%) & 3.90 \\
\hline 14. Evaluation and Feedback & $4 \mid(32.03 \%)$ & 40 (31.25\%) & $24(18.75 \%)$ & $10(7.81 \%)$ & $3(2.34 \%)$ & 3.59 \\
\hline
\end{tabular}

Note: The bold figures represent the highest number of response in each question.

Abbreviation: PBL, problem-based learning.

deficient in providing students with any or some of the skills necessary to obtain the knowledge needed. ${ }^{17}$

Making studying and learning easier is possible if students are well equipped with the needed study skills. Therefore, in our undergraduate medical curriculum, we designed a compulsory course of learning skills scheduled in the first semester of the 1st year to help our students learn more effectively and to facilitate them to become a lifelong learner. Students were advised to participate in the course actively due to its importance and its beneficial effects on their medical studies during the student life and life as a professional. Informal feedback from the students was obtained during the sessions and formal feedback was taken at the end of the course.

The present article investigated the efficiency and success of the learning skills course. From the literature search we found that this course is one of the most comprehensive learning skills offered in other medical schools around the world. This course in some schools is limited to the identification of students' individual learning styles, study skills, and approaches to learning by using inventories like learning and study strategies inventory. ${ }^{18-20}$ There are few published studies on this subject, a mandatory course of learning and study skills was designed in four metacognitive stages: knowledge, evaluation, planning, and monitoring. It was shown that after the training course, the students were able to apply the learning strategies and manage their learning but were unable to address the issue of motivation and professionalism. ${ }^{21,22}$ In the course which we have offered, many of the students clearly stated that now they know the meaning of a professional doctor and they are successfully applying the skills that they acquire in this course to other courses and they are benefiting from it. In order to evaluate the impact of the course on students, we analyzed their feedback. We found that all of the planned sessions were liked by the students and very few students gave negative comments for only few of the sessions. The success of the course was reflected by some of the remarks of the students in which they stated that the exam for this course should not be a written exam and as this course is about skills, it should be assessed by Objective Structured Clinical Exam or some other appropriate tools. These types of comments showed that our students in the first semester of the 1st year have clearly understood the philosophy of the education and they are now able to apply it.

After going through the experience of conducting this course and the analysis of the students' feedback, we concluded that the students overall had a positive attitude toward the learning skills course. Further, this course is likely to assist 1st year undergraduate medical students in improving their learning and adaptation to their medical curriculum. On the basis of our experience and observations, and the most important component; the feedback from the students, we came up with suggestions that the use of exercises and learning inventories (eg, learning styles and the process of PBL) are very interesting and beneficial, more activities like these should be included involving students eg, seminars and exercises; interactive sessions should be the cornerstone of the course and students can be asked to construct a portfolio, upon which they can be assessed as well. Since this course is intended to develop and foster learning skills, the assessment 
for this course should not be done by conventional tools like written exams but the tools like Objective Structured Clinical Exam, critical appraisal or reflections.

\section{Disclosure}

The authors have no conflicts of interest to disclose.

\section{References}

1. Chemers MM, Hu L, Garcia BF. Academic self-efficacy and first year college student performance and adjustment. Journal of Educational Psychology. 2001;93(1)55-64.

2. Dyrbye LN, Thomas MR, Shanafelt TD. Medical student distress: causes, consequences, and proposed solutions. Mayo Clin Proc. 2005; 80(12):1613-1622.

3. Birnie-Lefcovitch S. Student perceptions of the transition from high school to university: Implications for preventative programming. Journal of the First-Year Experience and Students in Transition. 2000;12(2):61-88.

4. Hawthorne L, Minas IH, Singh B. A case study in the globalization of medical education: assisting overseas-born students at the University of Melbourne. Med Teach. 2004;26(2):150-159.

5. Byrd DR, McKinney KJ. Individual, interpersonal, and institutional level factors associated with the mental health of college students. J Am Coll Health. 2012;60(3):185-193.

6. Beckert L, Wilkinson TJ, Sainsbury R. A needs-based study and examination skills course improves students' performance. Med Educ. 2003;37(5):424-428.

7. Wilkinsos TJ, Gill DJ, Fitzjohn J, Palmer CL, Mulder RT. The impact on students of adverse experiences during medical school. Med Teach. 2006;28(2):129-135.

8. Dyrbye LN, Thomas MR, Hushka MM, et al. A multicenter study of burnout, depression, and quality of life in minority and nonminority US medical students. Mayo Clin Proc. 2006;81(11):1435-1442.

9. Jaffri N, Jaleel A. Stress level in medical students. J Coll Physicians Surg Pak. 2012;22(6):416.
10. Abdulghani HM, AlKanhal AA, Mahmoud ES, Ponnamperuma GG, Alfaris EA. Stress and Its Effects on Medical Students: A Crosssectional Study at a College of Medicine in Saudi Arabia. $J$ Health Popul Nutr. 2011;29(5):516-522.

11. Stewart SM, Lam TH, Betson CL, Wong CM, Wong AM. A prospective analysis of stress and academic performance in the first two years of medical school. Med Educ. 1999;33(4):243-250.

12. Vitaliano PP, Maiuro RD, Mitchell E, Russo J. Perceived stress in medical school: resistors, persistors, adaptors and maladaptors. Soc Sci Med. 1989;28(12):1321-1329.

13. Dunn LB, Iglewicz A, Moutier C. A conceptual model of medical student well-being: promoting resilience and preventing burnout. Acad Psychiatry. 2008;32(1):44-53.

14. Behere SP, Yadav R, Behere PB. A comparative study of stress among students of medicine, engineering, and nursing. Indian J Psychol Med. 2011;33(2):145-148.

15. McGrady A, Brennan J, Lynch D, Whearty K. A Wellness Program for First Year Medical Students. Appl Psychophysiol Biofeedback. 2012;37(4):253-260.

16. Murdoch-Eaton D, Whittle S. Generic skills in medical education: developing the tools for successful lifelong learning. Med Educ. 2012;46(1): $120-128$.

17. Simanton E, Hansen L. Long-term retention of information across the undergraduate medical school curriculum. S D Med. 2012;65(7): 261-263.

18. Kolb DA. Experiential learning: Experience as the source of learning and development. New Jersey: Prentice-Hall; 1984.

19. Weinstein CE. LASSI user's manual. Clearwater, FL: H and H Publishing Company; 1987.

20. Barsch J. Barsch Learning Style Inventory. California: Arena Press; 1980.

21. Durak HI, Torun SE, Sayiner A, Kandiloglu G. Description and Evaluation of an Innovative Learning and Study Skills for the First Year Medical Students. Tohoku J Exp Med. 2006;210(3):231-237.

22. Huda N, Brula AQ. An introductory course on study skills forming a bridge between traditional and problem based learning (PBL). J Pak Med Assoc. 1999;49(2):27-30.
Advances in Medical Education and Practice

\section{Publish your work in this journal}

Advances in Medical Education and Practice is an international, peerreviewed, open access journal that aims to present and publish research on Medical Education covering medical, dental, nursing and allied health care professional education. The journal covers undergraduate education, postgraduate training and continuing medical education

\section{Dovepress}

including emerging trends and innovative models linking education, research, and health care services. The manuscript management system is completely online and includes a very quick and fair peer-review system. Visit http://www.dovepress.com/testimonials.php to read real quotes from published authors. 